Doi: $10.4274 /$ vhd.0005

Viral Hepatitis Journal 2018;24(1):3-6

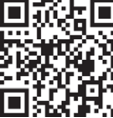

\title{
Hepatitis B and C Sero-prevalence in Patients with Human Immunodeficiency Virus/Acquired Immune Deficiency Syndrome at a Tertiary Care Hospital in Izmir
}

\author{
Izmir'de Üçüncü Basamak Bir Hastanede Insan Immün Yetmelik Virüsü/Edinsel \\ Bă̆ıșıklık Yetmezliği Sendromu Olgularında Hepatit B ve C Sero-prevalansı
}

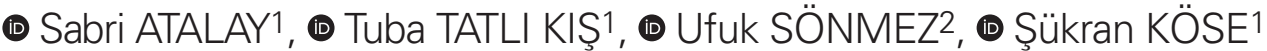 \\ 1 University of Health Sciences, Izmir Tepecik Training and Research Hospital, Clinic of Infectious Diseases and Clinical Microbiology, Izmir, Turkey \\ 2 University of Health Sciences, Izmir Bozyaka Training and Research Hospital, Clinic of Infectious Diseases and Clinical Microbiology, Izmir, Turkey
}

\begin{abstract}
Objectives: Infections caused by human immunodeficiency virus (HIV), hepatitis B virus (HBV) and hepatitis C virus (HCV) represent a significant health problem. Co-infection with these viral agents is not uncommon as a result of the similar transmission routes. Our study was planned to investigate the prevalence of $\mathrm{HBV}$ and $\mathrm{HCV}$ infections in HIV/Acquired Immune Deficiency syndrome (AIDS) patients followed up at our institution.

Materials and Methods: In this study conducted in the Department of Infectious Diseases and Clinical Microbiology at Izmir Tepecik Training and Research Hospital, medical records of patients followed at the HIV/AIDS outpatient clinic between August 2002 and December 2014 were evaluated. Demographic data, main route of HIV transmission, hepatitis B surface antigen (HBsAg), anti-hepatitis B core $(\mathrm{HBC})$ immunoglobulin $\mathrm{G}(\mathrm{lgG})$, anti-HBs and anti-HCV results were evaluated.

Results: A total of 157 treatment-naive patients who were followed up at our HIVIAIDS outpatient clinic were included in this study. Four patients (2.6\%), had HBsAg positivity. Anti-HBc IgG and antiHBs positivity were detected in $34 \%$ and $28.4 \%$ of the patients, respectively. No patients had anti-HCV positivity.

Conclusion: The prevalence of HBsAg in HIV-positive individuals was found to be similar to that in other population-based studies in our country. Absence of anti-HCV positivity suggests that hepatitis C infection is not a major health problem in this population.

Keywords: Human immunodeficiency virus, hepatitis B virus, hepatitis $\mathrm{C}$ virus, seroprevalence
\end{abstract}

ÖZ

Amaç: Insan immün yetmelik virüsü (HIV), hepatit $B$ virüsü $(\mathrm{HBV})$ ve hepatit $\mathrm{C}$ virüsünün $(\mathrm{HCV})$ neden olduğu enfeksiyonlar önemli bir sağlık sorunudur. Bulaş yollarının benzerliği nedeni ile bu enfeksiyonların birlikteliği (ko-enfeksiyonu) nadir değildir. Çalışmamızda kliniğimizde HIV/Edinsel Bağışılıı Yetmezliği sendromu (AIDS) tanısı ile takip edilen hastalarda HBV ve HCV prevalansının incelenmesi amaçlanmıştır.

Gereç ve Yöntemler: Izmir Tepecik Eğitim ve Araştırma Hastanesi'nde Ağustos 2002-Arallı 2014 tarihleri arasında HIV/AIDS tanısıyla takipli hastalar retrospektif olarak incelendi. Demografik özellikler, HIV'nin en olası geçiş yolu ve hepatit B yüzey antijeni (HBsAg), anti-hepatit B çekirdeği (HBc) immünoglobülin G (lgG), anti$\mathrm{HBs}$ ve anti-HCV sonuçları değerlendirildi.

Bulgular: Bu çalışmaya, polikliniğimizde takip edilen 157 naiv HIVIAIDS hastası dahil edildi. Dört hastada $(\% 2,6)$ HBsAg pozitifliği saptand. Anti-HBc lgG ve anti-HBs pozitifliği sırasılyla $\% 34$ ve $\% 28,4$ saptanmış olup, hiç bir hastada anti-HCV pozitifliği saptanmamıştır.

Sonuç: HIV pozitif kişilerde HBsAg sıklğı ülkemizde yapılmış popülasyon tabanlı diğer çalış̧malar ile benzer oranda saptanmıştır. Anti-HCV pozitifliginin olmaması, hepatit C enfeksiyonunun bu hasta grubunda önemli bir sağlık problemi olmadı̆̆ını düşündürmektedir.

Anahtar Kelimeler: Insan immün yetmezlik virüsü, hepatit B virüsü, hepatit C virüsü, seroprevalans

Atalay S, Tatlı Kıș T, Sönmez U, Köse Ş. Hepatitis B and C Sero-prevalence in Patients with Human Immunodeficiency Virus/Acquired Immune Deficiency Syndrome at a Tertiary Care Hospital in Izmir. Viral Hepat J. 2018;24:3-6. 


\section{Introduction}

Infections caused by human immunodeficiency virus (HIV), hepatitis B virus (HBV) and hepatitis C virus (HCV) represent a significant health problem. Co-infection with these viral agents is not uncommon as a result of the similar of transmission routes. The main transmission routes of HBV infection among adults are sexual intercourse or intravenous (i.v.) drug use in low endemic countries, while horizontal and vertical transmission in high endemic countries (1). Hepatitis C is mainly transmitted through contaminated blood, as is also the case with HIV (2).

By the end of the year 2015, approximately 70 million people have been infected with HIV and 35 million deaths have occurred, with approximately 36.7 million people currently living with HIV (3). With respect to HBV, more than two billion people have been infected with this virus worldwide, and 350 to 400 million people are chronic carriers (4). The number of individuals living with chronic HCV infection exceeds 130 million (5). Among HIV-infected individuals, variable rates of HBV co-infection have been reported, ranging from $6 \%$ to $14 \%(6)$, and approximately $20-30 \%$ of HIVpositive individuals are also infected with HCV (7). The rates of HIV-HCV co-infection vary widely in different population groups depending on the geographical region, risk factors, age of infection, modes of transmission, and types of exposure (8).

The introduction of highly active antiretroviral therapy (HAART) has significantly improved the survival in patients infected with HIV (9). However, liver disease caused by HBV and HCV co-infections, chronic alcohol abuse, hepatic tuberculosis or hepatotoxicity due to antiretroviral drugs have now emerged as a major cause of mortality in these patients $(10,11)$. In co-infected patients, these viruses have significant interaction, amplifying the pathogenicity of individual agent, leading to higher morbidity and mortality $(12,13)$. HIV infection is associated with an acceleration of the course of liver diseases caused by hepatitis B and C, particularly in patients with more pronounced immune deficiency. Thus, co-infected patients have more severe outcomes than monoinfected patients. From a clinical viewpoint, HIV-HBV co-infection is more severe and is associated with higher rates of cirrhosis and hepatocellular carcinoma. In such cases, the risk of cirrhosis increases 4.2-fold with an associated elevation in mortality, and, in some cases, HBV can be reactivated $(14,15,16)$. Several studies have shown that HIV-HCV co-infected patients are also at an increased risk of more rapid progression to cirrhosis, end-stage liver disease and hepatocellular carcinoma (8). Therefore, an earlier recommendation by the World Health Organization involved the commencement of HAART in HIV patients co-infected with HBV or HCV (17). This recommendation has recently been modified as to treat all patients irrespective of CD4 count. However, treatment in co-infected patients should be considered a priority, as a potential means to reduce liver-associated morbidity and mortality. Turkey is considered a low endemic country for HIV and $\mathrm{HCV}$, and a low/intermediate endemic country (depending on the geographical region) for HBV infection. However, as opposed to the epidemiology of $\mathrm{HBV}$ and $\mathrm{HCV}$, a recent rise in the number of HIV-infected individuals has been noted. On the other hand, there is a scarcity of studies examining this population in our country. Thus, this retrospective study was planned to investigate the prevalence of $\mathrm{HBV}$ and $\mathrm{HCV}$ infections in HIV/Acquired
Immune Deficiency syndrome (AIDS) patients followed up at our institution.

\section{Materials and Methods}

In this study conducted at the Department of Infectious Diseases and Clinical Microbiology, Tepecik Training and Research Hospital, medical records of patients followed at the HIVIAIDS outpatient clinic between August 2002 and December 2014 were evaluated. Demographic data, potential route of HIV transmission, and hepatitis B surface antigen (HBsAg), anti-hepatitis B core ( $\mathrm{HBc}$ ) immunoglobulin $\mathrm{G}(\mathrm{IgG})$, anti-HBs and anti-HCV results based on enzyme-linked immunosorbent assay (ELISA) (Diasorin Diagnostic Specialist S.T.A., Italy) at the time of presentation were recorded. The results were classified as positive or negative using the cut-off values provided by the manufacturer. Patients with missing data or incompliance to follow-up visits were excluded. Therefore, some of the statistical procedures did not involve the whole patient population enrolled.

\section{Results}

In this study, we included a total of 157 treatment-naive patients with anti-HIV positivity based on ELISA and confirmatory Western blot test who were followed up at our HIV/AIDS outpatient clinic. The mean age was 41 years (16-79 years), and 28 patients (18\%) were female. Heterosexual intercourse was the most likely mode of transmission in $64.9 \%$. Other potential routes of transmission were as follows in the decreasing order of frequency: bisexual/ homosexual intercourse, unknown, medical intervention/blood transfusion, and i.v. drug use (Table 1, 2). Four patients $(2.6 \%)$, one of whom was a female, had HBsAg positivity. Anti-HBc IgG and anti-HBs positivity were detected in $34 \%$ and $28.4 \%$ of patients, respectively. No patients had anti-HCV positivity. Also, among 5554 subjects with HBV and 182 subjects with HCV followed up in our outpatient unit, none were anti-HIV-positive.

\section{Discussion}

According to the Turkish National Health Agency 2016 data, there were a total of $12.281 \mathrm{HIV}$-positive patients in Turkey, which is a low prevalence country. However, a recent and significant increase has occurred in the number of newly detected cases, with 1734 patients reported until December 2016 in the past year. Of these newly identified subjects, $84 \%$ were male and $16 \%$ were female; and $16.5 \%$ were non-nationals. Higher representation of young adults between 25 and 29 years of age was also noteworthy.

\begin{tabular}{|l|l|l|}
\hline \multicolumn{3}{|l|}{ Table 1. Main transmission route for the patients } \\
\hline Transmission route & Number & $\%$ \\
\hline Heterosexual intercourse & 102 & 64.9 \\
\hline Homo/bisexual intercourse & 38 & 24.2 \\
\hline Medical intervention/Blood transfusion & 7 & 4.5 \\
\hline Unknown & 8 & 5.1 \\
\hline i.v. drug user & 2 & 1.3 \\
\hline Total & 157 & 100 \\
\hline i.v.: Intravenous & \multicolumn{3}{|l}{} \\
\hline
\end{tabular}


There were only 529 new HIV-positive cases in 2010, and a more than 5-fold increase was found in 2015 reaching 2.130 new cases (18).

Despite the regional variation in terms of HBV seroprevalence in Turkey, a trend toward a declined prevalence was observed probably due to the impact of routine nationwide childhood immunization program initiated in 1998. In a previous review, the reported rate of HBsAg seroprevalence in the general Turkish population was 2.5 to $9 \%$ (19), which is comparable to the prevalence of HBV infection among HIV patients in our study, i.e. 2.6\%. However, in another multi-center study from Turkey reported a higher rate of $\mathrm{HBsAg}$ positivity (6.2\%) among HIV-positive individuals (20). In the same study, $0.9 \%$ of subjects were anti-HCV positive. Similar results of HBsAg positivity (4.4\%) was reported in a study conducted by Inci et al. (21). In another study conducted with 70 (56 males, 14 females) HIV-infected patients, HBV and HCV co-infection rates were $14.2 \%$ and $12.8 \%$, respectively while four $(5.7 \%)$ patients were found to be infected with HBV, HCV and HIV (22). Immunity against hepatitis $\mathrm{B}$ infection i.e. anti-HBs and anti-HBc lgG positivity was observed in $28.4 \%$, isolated anti-HBc IgG positivity was observed in $1.9 \%$, isolated anti-HBs positivity was observed in $9.03 \%$ of this population. This finding is consistent with the fact that the study participants were mostly middle-aged subjects who did not benefit from the routine vaccination program initiated in 1998. On the other hand, exposure to hepatitis B (anti-HBc IgG) was found in a greater proportion (34\%) of these subjects. Overall, these data underscore the high level of HBV co-infection risk in HIV-positive subjects and underlie the importance of vaccination, particularly when one considers the recent findings showing a high representation of young adults among newly diagnosed patients with HIV positivity.

$\mathrm{HCV}$ infection is more likely occur in specific circumstances and specific patient groups with certain risks. In a study by Freitas et al. (23), HIV-HCV co-infection was more likely to be associated with an age over 40 years, i.v. drug use, blood transfusion, and the absence of a steady partnership 8. The prevalence of HIV/HCV co-infection varies from one country to another depending on the route of HIV transmission: $10.8-42 \%$ in Brazil, 25\% in the United States, 56.7\% in Australia and $58.5 \%$ in Argentina.

Since i.v. drug use represents the main route of $\mathrm{HCV}$ transmission, HIV-HCV co-infection rates are higher among HIV/ AIDS patients with i.v. drug use. High HIV-HCV co-infection rates

\begin{tabular}{|c|c|c|c|}
\hline Serological marker & $n$ & $\begin{array}{l}\text { Total } \\
\text { patients }\end{array}$ & $\%$ \\
\hline $\begin{array}{l}\text { HBsAg positive and anti-HBc lgG } \\
\text { positive }\end{array}$ & 4 & 155 & 2.6 \\
\hline Isolated anti-HBc IgG positive & 3 & 155 & 1.9 \\
\hline $\begin{array}{l}\text { Anti-HBc lgG positive and anti-HBs } \\
\text { positive }\end{array}$ & 44 & 155 & 28.4 \\
\hline Anti-HBc IgG positivity total & 51 & 150 & 34 \\
\hline Isolated anti-HBs positive & 14 & 155 & 9.03 \\
\hline Anti-HCV positive & 0 & 155 & 0 \\
\hline
\end{tabular}

(approximately 70\%) have been reported in Eastern European countries and in Iran where i.v. drug use is the main route of HIV transmission (20). In a study of 378 HIV-positive individuals in Kenya, 1\% was found to be co-infected with HCV (24). Again, in a cohort of 138 HIV-positive patients in Ghana, HCV co-infection was found in $3.6 \%$ (25). In a meta-analysis of studies reporting $\mathrm{HCV}$ prevalence amongst HIV patients in sub-Saharan Africa, the mean prevalence of co-infection was 7\% (26). According to 20082012 data from the Turkish Red Crescent Blood Center, anti-HCV was found to be positive in 0.02 to $0.004 \%$ of a total of civilian donor population of $4.510 .207(27,28)$. The study conducted by the Turkish Association for the Study of the Liver between 2008 and 2011 found that $0.95 \%$ of 5.471 subjects were positive for $\mathrm{HCV}$ (29). The prevalence of anti-HCV positivity in the general Turkish population has been reported to be 1-2.2\% (30). A number of factors, including anal sex, multiple partners, and co-infection with HIV and other sexually transmitted diseases, have been implicated in the increase in HCV seroconversion among HIVpositive men who have sex with men (MSM) $(31,32)$. In this study, no anti-HCV positivity was found in this population of patients infected with HIV, possibly related to the difference in transmission routes of HIV among patients included in this study. Accordingly, heterosexual intercourse was reported to be the main route of transmission, and relatively low numbers of patients were MSM/ bisexual (24.2\%) and i.v. drug users (1.3\%). In a previous study conducted in Turkey, the prevalence of i.v. drug use was $0.05 \%$ in the general population (33). Although heterosexual intercourse was reported to be the main route of HIV transmission, the significantly higher proportion of male participants suggests that the actual number of individuals experiencing same-sex intercourse may be higher. On the other hand, individuals may opt to conceal their sexual preferences due to a number of factors such as fear of stigmatization or disclosure. Thus, absence of antiHCV-positive patients in our sample is most likely due to the low number of i.v. drug users and low HCV prevalence nationwide. All HIV-infected patients should be tested for HCV infection. False negative anti-HCV results may be seen in HIV-positive individuals with low CD4 (<100/mm3) counts. If anti-HCV is negative and HCV infection is still suspected, HCV RNA should be performed (5).

\section{Study Limitations}

Certain limitations of our study should be mentioned. It was a single-center study from western Turkey with a small sample size, restricting its ability to reflect the current status in the country.

\section{Conclusion}

As a conclusion, it confirms the previous national data indicating a high prevalence of $\mathrm{HBsAg}$ among HIV-positive individuals and emphasizing the requirement for effective immunization in susceptible populations. Absence of anti-HCV positivity suggests that HCV infection may not represent a major health problem in our population.
Ethics
Ethics Committee Approval: Retrospective study.
Informed Consent: Retrospective study.
Peer-review: Externally and internally peer-reviewed. 


\section{Authorship Contributions}

Surgical and Medical Practices: S.A., U.S., Concept: S.A., Design: S.A., Data Collection or Processing: U.S., T.T.K., Analysis or Interpretation: S.A., U.S., T.T.K., Literature Search: S.A., S..K. Writing: S.A., T.T.K.

Conflict of Interest: No conflict of interest was declared by the authors.

Financial Disclosure: The authors declared that this study received no financial support.

\section{References}

1. Martin S, Livramento Ad, Andrigueti M, Kretzer IF, Machado MJ, Spada C, Treitinger A. The prevalence of hepatitis B virus infection markers and socio-demographic risk factors in HIV-infected patients in Southern Brazil. Rev Soc Bras Med Trop. 2014;47:552-558.

2. Braga WS, da Costa Castilho M, Santos IC, Moura MA, Segurado AC. Low prevalence of hepatitis $B$ virus, hepatitis $D$ virus and hepatitis virus among patients with human immunodeficiency virus or acquired immunodeficiency syndrome in the Brazilian Amazon basin. Rev Soc Bras Med Trop. 2006;39:519-522.

3. http://www.who.int/gho/hiv/en/

4. Dény P, Zoulim F. Hepatitis B virus: From diagnosis to treatment. Pathol Biol (Paris). 2010:58:245-253.

5. Clausen LN, Lundbo LF, Benfield T. Hepatitis $C$ virus infection in the human immunodeficiency virus infected patient. World $J$ Gastroenterol. 2014;20:12132-12143.

6. Alter MJ. Epidemiology of viral hepatitis and HIV co-infection. J Hepatol. 2006;44(Suppl 1):6-9.

7. Vester A. HIV and co-infections in people who inject drugs. Geneva: WHO/Department HIV/AIDS;2012. Available from: http:// www.unaids.org/en//edia/unaids/contentassets/documents/ pcb/2012/20120612_Annette_Verster_presentation.pdf

8. Freitas SZ, Teles SA, Lorenzo PC, Puga MA, Tanaka TS, Thomaz DY, Martins RM, Druzian AF, Lindenberg AS, Torres MS, Pereira SA, Villar LM, Lampe E, Motta-Castro AR. HIV AND HCV Co-infection: Prevalence, Associated Factors and Genotype Characterization In The Midwest Region of Brazil. Rev Inst Med Trop Sao Paulo. 2014:56:517-524

9. Data Collection on Adverse Events of Anti-HIV drugs (D:A:D Study Group, Smith C, Sabin CA, Lundgren JD, Thiebaut R, Weber R, Law M, Monforte Ad, Kirk O, Friis-Moller N, Phillips A, Reiss P, El Sadr W, Pradier C, Worm SW. Factors associated with specific causes of death amongst HIV-positive individuals in the D:A:D Study. AIDS. 2010;24:1537-1548.

10. Li YJ, Wang HL, Li TS. Hepatitis B virus/human immunodeficiency virus co-infection: interaction among human immunodeficiency virus infection, chronic hepatitis B virus infection, and host immunity. Chin Med J (Engl). 2012;125:2371-2377.

11. Singhatiraj E, Suri J, Goulston C. HIV co-infections with hepatitis B and C. J AIDS Clin Res. 2012;3:1-12.

12. Oliveira SB, Merchán-Hamann E, Amorim LD. HIV/AIDS co-infection with the hepatitis B and C viruses in Brazil. Cad Saúde Pública. 2014;30:433-438.

13. Mendes-Corrêa MC, Barone AA, Cavalheiro Nd, Tengan FM, Guastini C. Prevalence of hepatitis B and C in the sera of patients with HIV infection in São Paulo, Brasil. Rev Inst Med Trop São Paulo. 2000;42:81-85.

14. Amaral ISA, Almeida ML, Alves FT, Móia LJMP; Conde SRSS. Epidemiologia de pacientes coinfectados HIV/HCV atendidos na Fundação Santa Casa de Misericórdia do Pará. Rev Para Med. 2007;21:15-24.

15. Soriano V, Puoti M, Bonacini M, Brook G, Cargnel A, Rockstroh J, Thio C, Benhamou Y. Care of patients with chronic hepatitis B and
HIV co-infection: recommendations from an HIV-HBV international panel. AIDS. 2005;19:221-240.

16. Patel $\mathrm{P}$, Davis $\mathrm{S}$, Tolle M, Mabikwa V, Anabwani G. Prevalence of hepatites $B$ and hepatitis $C$ coinfections in an adult HIV centre population in Gaborone, Botswana. Am J Trop Med Hyg. 2011:85:390-394

17. WHO. Rapid advice: antiretroviral therapy for HIV infection in adults and adolescents. November 2009

18. https://www.thsk.gov.tr/guncel/haberler/198-bulasici-hastaliklardaire-baskanligi-haberler/dunya-aids-gunu.html

19. Hahné SJ, Veldhuijzen IK, Wiessing L, Lim TA, Salminen M, Laar Mv. Infection with hepatitis B and C virus in Europe: a systematic review of prevalence and cost-effectiveness of screening. BMC Infect Dis. 2013;13:181.

20. Aydin OA, Yemisen M, Karaosmanoglu HK, Sargin F, Gunduz A, Ceylan B, Mete B, Ozgunes N, Sevgi DY, Ozaras R, Tabak F. Low Prevalence of Hepatitis C Virus Infection Among HIV-Positive Patients: Data From a Large-Scale Cohort Study in Istanbul, Turkey. Hepat Mon. 2014;14:18128.

21. Inci A, Fincancı M, Soysal F. HIV/HBV Koenfeksiyonlu Olguların Değerlendirilmesi. J Clin Anal Med. 2015;6:439-442.

22. Ural S, Kaptan F, Türker N, Örmen B, El S, Coșkun NA, Demir C, Türker M. Seroprevalance of Hepatitis B Virus and Hepatitis C Virus Infections in Human Immunodeficiency Virus-Infected Patients. Klimik Dergisi. 2010;23:100-104.

23. Freitas SZ, Teles SA, Lorenzo PC, Puga MA, Tanaka TS, Thomaz DY, Martins RM, Druzian AF, Lindenberg AS, Torres MS, Pereira SA, Villar LM, Lampe E, Motta-Castro AR. HIV and HCV coinfection: prevalence, associated factors and genotype characterization in the Midwest Region of Brazil. Rev Inst Med Trop Sao Paulo. 2014; $56: 517-524$

24. Harania RS, Karuru J, Nelson M, Stebbing J. HIV, hepatitis B and C co-infection in Kenya. AIDS. 2008;22:1221-1222.

25. Sagoe KW, Agyei AA, Ziga F, Lartey M, Adiku TK, Seshi M, Arens $\mathrm{MQ}$, Mingle JA. Prevalence and impact of hepatitis B and C virus co-infections in antiretroviral treatment naïve patients with HIV infection at a major treatment centre in Ghana. J Med Virol. 2012;84:6-10.

26. Barth RE, Huijgen Q, Taljaard J, Hoepelman Al. Hepatitis B/C and HIV in sub-Saharan Africa: an association between highly prevalent infectious diseases. A systematic review and metaanalysis. Int J Infect Dis. 2010;14:1024-1031.

27. Mıstık R. Türkiye'de viral hepatit epidemiyolojisi- Yayınların irdelenmesi. Içinde: Tabak F, Balık I, Tekeli E (eds.), Viral Hepatitle Savaşım Derneği Yayını, İstanbul Medikal Yayıncılık, Istanbul; 2007; p. 9-50.

28. Tosun S. Türkiye'de viral hepatit B Epidemiyolojisi-Yayınların Metaanalizi. Içinde: Tabak F, Tosun S (eds.), Viral Hepatitle Savaşım Derneği Yayını, Istanbul Medikal Yayıncılık, Istanbul; 2013; p. 25-81.

29. Tosun S. Viral hepatitlerin ülkemizdeki değișen epidemiyolojisi. ANKEM Derg. 2013;27(Özel Sayı 2):128-134

30. Hahné SJ, Veldhuijzen IK, Wiessing L, Lim TA, Salminen M, Laar Mv. Infection with hepatitis B and C virus in Europe: a systematic review of prevalence and cost-effectiveness of screening. BMC Infect Dis. 2013;13:181.

31. Naggie S, Sulkowski MS. Management of patients co-infected with HCV and HIV: a close look at the role for direct-acting antivirals. Gastroenterology. 2012;142:1324-1334.

32. Taylor LE, Swan T, Mayer KH. HIV co-infection with hepatitis C virus: evolving epidemiology and treatment paradigms. Clin Infect Dis. 2012;55(Suppl 1):33-42.

33. Ministry of Interior General Directorate of Security. TC drug report Ministry of Interior General Directorate of Security Department of Anti-Smuggling and Organized Crime. Ankara; 2013. 